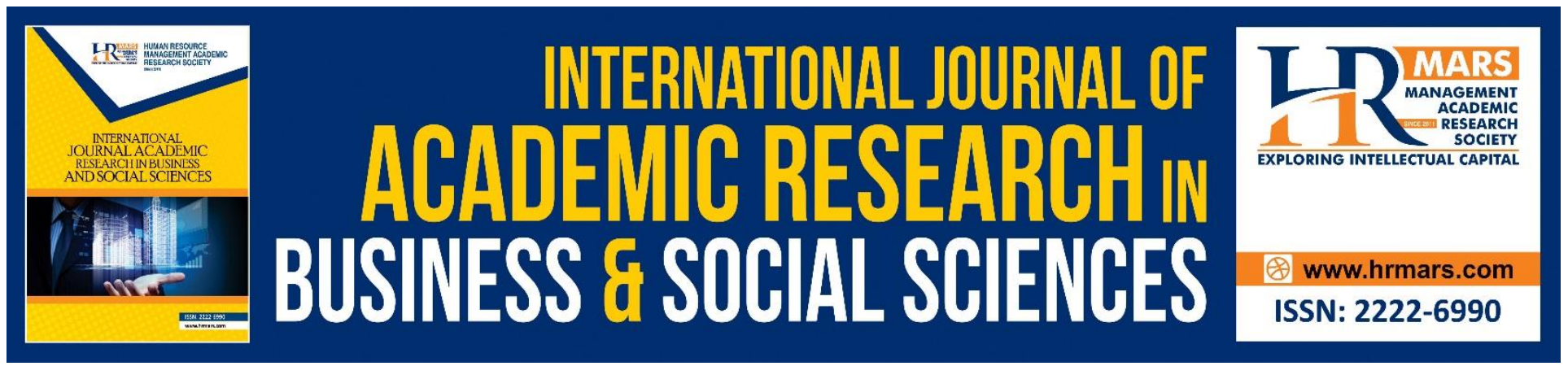

\title{
Teaching Present Continuous Sentence with Rainbow Tower in Rural Primary School
}

Jashil Lahung Lau, Estee-Laura Anak Anthony and Melor Md Yunus

To Link this Article: http://dx.doi.org/10.6007/IJARBSS/v9-i2/5588 $\quad$ DOI: $10.6007 /$ IJARBSS/v9-i2/5588

Received: 20 Jan 2019, Revised: 23 Feb 2019, Accepted: 10 March 2019

Published Online: 13 March 2019

In-Text Citation: (Lau, Anthony, \& Yunus, 2019)

To Cite this Article: Lau, J. L., Anthony, E.-L. A., \& Yunus, M. M. (2019). Teaching Present Continuous Sentence with Rainbow Tower in Rural Primary School. International Journal of Academic Research in Business and Social Sciences, 9(2), 538-544.

Copyright: (c) 2019 The Author(s)

Published by Human Resource Management Academic Research Society (www.hrmars.com)

This article is published under the Creative Commons Attribution (CC BY 4.0) license. Anyone may reproduce, distribute, translate and create derivative works of this article (for both commercial and non-commercial purposes), subject to full attribution to the original publication and authors. The full terms of this license may be seen at: http://creativecommons.org/licences/by/4.0/legalcode

Vol. 9, No. 2, 2019, Pg. 538 - 544

http://hrmars.com/index.php/pages/detail/IJARBSS

JOURNAL HOMEPAGE

Full Terms \& Conditions of access and use can be found at http://hrmars.com/index.php/pages/detail/publication-ethics 


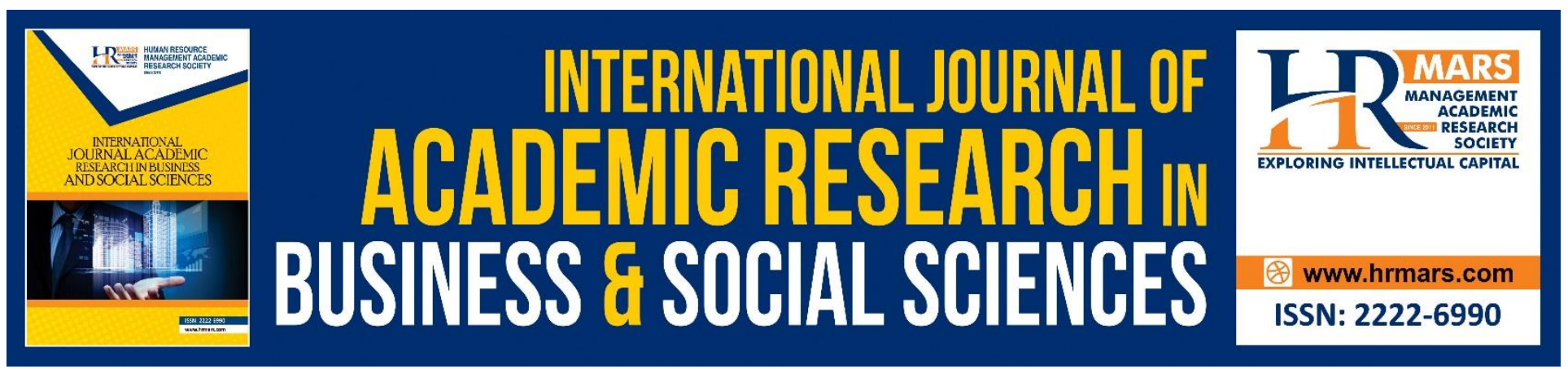

\title{
Teaching Present Continuous Sentence with Rainbow Tower in Rural Primary School
}

\author{
Jashil Lahung Lau ${ }^{1}$, Estee-Laura Anak Anthony ${ }^{2}$ and Melor Md \\ Yunus ${ }^{3}$ \\ ${ }^{1}$ Sekolah Kebangsaan Long Panai, D/A PPD Baram, 98050 Baram, Sarawak. \\ ${ }^{2}$ Sekolah Kebangsaan Sungai Genaan, D/A PPD Sebauh, 97100 Bintulu, Sarawak. \\ ${ }^{3}$ Faculty of Education, Universiti Kebangsaan Malaysia (UKM), 43600 Bangi, Selangor.
}

Abstract: This research aimed at studying the ability of using the Rainbow Tower to teach primary rural school pupils to write present continuous sentence. This study also aimed to learn the effect of using this innovation whether it improved the pupils writing skills. The sample for this research was of 8 pupils from two schools in the interior of Sarawak. They were chosen based on their midterm assessment's results and some document analysis. A mixed method design was used where the quantitative data obtained from the pre-test and post-test conducted is used to measure the pupils' capability of constructing present continuous sentence before and after using the Rainbow Tower to learn sentence construction. To further understand about the effectiveness of the Rainbow Tower, semi-structured interviews were carried out and their responses were recorded using a checklist prepared beforehand. The research highlights that with the aid of the intervention, pupils were able construct present continuous sentence. Based on the participants' responses, their writing skills were seen to improve positively after they used Rainbow Tower to construct sentences during writing lessons. With this innovation, it was hoped to be able to be beneficial for both teachers and pupils as an alternative yet interesting teaching tool to teach sentence construction.

Keywords: Rainbow Tower; Writing Skill; ESL Learners, Fun Learning, Action Research

\section{Introduction}

Being a difficult skill to learn and master, it is a must to learn for educational and communicational purposes(Bipinchandra et al., 2014; Graham, Gillespie, \& Mckeown, 2013). Although recognized as the killer subject due to the writing parts in the Year 6 public examination "Ujian Pencapaian Sekolah Rendah" (Yunus \& Chan, 2016), writing skills is said to be a surviving skill (Yunus, Salehi, Amin, Shojaee, \& Wang, 2016), is able to help to develop and support listening, speaking and reading skills (Huy, 2015)thus improving their English competency (Madut \& Yunus, 2016). Being one of the most difficult parts to teach (Graham et al., 2013), it is however a must-learned and master skill for 
academical and communication purpose(Kurasaki, Bloor, Sy, \& Huguenin, 2017). Malaysia has long been having English as a compulsory subject to be learn. It is an essential to equip our younger generation with the language to face the economy challenges in years to come(Suran \& Yunus, 2016). Despite that, young graduates seem to unable to master the language yet to be less than proficiency which has become a concern in almost every working industry (Tan, 2017). Worrying about the future of the younger generation, the Ministry of Education has set a target, that towards the end of six years in primary school, every child should be able to write different types of written materials using the language, style and forms appropriately (Suran \& Yunus, 2016). However, Malaysian young learners, especially in rural primary school are still facing difficulties learning writing. Therefore, we had developed a kinaesthetic writing tool which was based on the Montessori Pink Tower. Kinaesthetic leaners can remember information longer when learning involves physical movements as this connects both parts of the brain that activates language learning and movement (Toikka, 2016). Thus, by interacting with their learning materials, learners can learn and retain the knowledge longer(Uzho \& Salame, 2016).

Writing is a complex skill that has rules, forms and styles with different strategies and process to direct one's thoughts (Graham et al., 2013; Huy, 2015; Kurasaki et al., 2017; Myhill, Jones, \& Wilson, 2016). It is believed to be a crucial and comprehensive skill that helps improve English language learner's grammar, vocabulary, and elements such as planning editing and revising(Lim, Yunus, \& Embi, 2017). Previous studies about learning writing stated that using conventional method can bore the learners learning the skill (Abdi, 2014; Madut \& Yunus, 2016; Mokhtar, 1989) where the learners are usually in a passive manner and it is a teacher-centered learning environment (Yap, 2016). Another study suggested that due to teacher's teaching methods and the type of writing activities, pupils may face difficulties in transferring their ideas into written form (Yunus \& Chan, 2016). A study in Ethiopia and Libya suggested that English language practitioners were find out to always option to the traditional method of teaching while focusing on writing with the aim to pass the exam paper(Jha, 2014). Jha (2014) further researched that the learners did not master English despite learning the language for several years. Some researchers stated that conventional methods may be applicable on high proficiency pupils, however, may neglect low proficiency pupils and kinaesthetic pupils (Toikka, 2016). He further suggested that kinaesthetic learning style is suitable for learning in a classroom as it is beneficial to all pupils regardless the learning styles. This was supported by Nunes (2018)who did a research that concludedabout kinaesthetic learning being the best result during learning as the participants then required less support.

The two schools had identified similar problems regarding the learning of writing in their Year 4 classrooms. The conventional methods such as drilling, chalk and talk had less improvement than expected causing the pupils to unable to master constructing present continuous sentences. Therefore, this research aims to study about the effectiveness of using Rainbow Tower in teaching Present Continuous Sentence construction and to what extent does the Rainbow Tower can affect in pupils' sentence writing.

\section{Materials and Methods}

This research was chosen from one of teaching experiences encountered by the first and second authors. Both authors found similarity among their Year 4 pupils in their respective schools 
struggling in constructing present continuous sentences correctly. Knowing it was one of the learning standards that must be achieved, the authors therefore conducted an action research based on Stephen Kemmis's model to study the effect of using Rainbow Tower to teach present continuous sentences among Year 4 rural primary school pupils.

In keeping with the aim of this research, this article focused on the students' improvement on the ability of constructing present continuous sentences and their views on learning writing skill using Rainbow Tower. The respondents were 4 pupils from School A and 4 pupils from School B. These pupils were purposely selected based on their performance in last midterm test where all of them scored less than satisfactory marks in Section C for the English Paper 2 and their daily task during writing lessons.

A Pre-Test and a Post-Test with a set of similar questions and sentence construction structures were implemented in this research. Results from both tests were used to measure pupils' ability in constructing present continuous sentences. Each question which consisted of a picture and keywords was prepared with standardized difficulty level. After the Pre-Test, the intervention was carried out twice a week for 2 weeks. A Post-Test was administered followed by a semi-structured interview with a checklist to identify to what extent the intervention improves sentence construction.

For each Pre-test and Post-Test, the participants had answered 10 questions each. These were to identify the mastery level of the participants on their ability to construct present continuous sentence before and after the intervention was conducted. The Rainbow Tower helped the participants to construct sentences by arranging the words based on their colour codes. The vocabulary used in the sentence construction was taken from the learning of the day - Topic 8: Fascinating Sabah and Sarawak of the Year 4 English Language Textbook.

During the intervention, participants were introduced to the part of speech and its colour coding namely Subject (red), Verb To Be (orange), Verb (yellow), Object (green), Place (blue), Time (indigo), and Full Stop (violet), and its sequence to form the Rainbow Tower. Participants would practice using the Rainbow Tower to arrange the words in sequence to form complete present continuous sentences until they were able to construct the sentences without the aid of the intervention anymore. Subsequent to the Post-Test, the results were analyzed and compared among the two schools to learn about the pupils' progress. By the end of the cycle, an interview was conducted with each of the participants with all the pupils, covering 4 main questions in order to gain their perceptions about the teaching and learning session using the Rainbow Tower.

\section{Findings and Discussion}

The scores obtained from the Pre-Test and Post-Test were compared to find the level of understanding towards constructing present continuous sentences among the participants. After the intervention was carried out, it had shown a significant increase in terms on the level of understanding among the participants. 
INTERNATIONAL JOURNAL OF ACADEMIC RESEARCH IN BUSINESS AND SOCIAL SCIENCES Vol. 9, No. 2, Feb, 2019, E-ISSN: $2222-6990$ @ 2019 HRMARS

Table 1: Respondents' scores between Pre-Test and Post-Test.

\begin{tabular}{|l|l|l|l|l|}
\hline & Participants & $\begin{array}{l}\text { Score } \\
\text { (Pre-Test) }\end{array}$ & $\begin{array}{l}\text { Score } \\
\text { (Post Test) }\end{array}$ & $\begin{array}{l}\text { Percentage } \\
\text { increment }\end{array}$ \\
\hline \multirow{3}{*}{ School A } & A & 2 & 9 & $70 \%$ \\
\cline { 2 - 5 } & B & 3 & 10 & $70 \%$ \\
\cline { 2 - 5 } & C & 2 & 8 & $60 \%$ \\
\cline { 2 - 5 } & D & 1 & 8 & $70 \%$ \\
\hline \multirow{3}{*}{ School B } & Mean Score & 2 & 8.8 & $67.5 \%$ \\
\cline { 2 - 5 } & E & 1 & 8 & $70 \%$ \\
\cline { 2 - 5 } & G & 2 & 9 & $70 \%$ \\
\cline { 2 - 5 } & H & 2 & 9 & $80 \%$ \\
\hline & Mean Score & 1.5 & 8.5 & $70 \%$ \\
\hline & Total Mean score & 1.8 & 8.6 & $70 \%$ \\
\hline
\end{tabular}

Based on the table above, the respondents from both schools elicit excellent after the intervention was implemented, with one of them scored $100 \%$ for the Post Test (Respondent B). The percentage of increment for School A was $67.5 \%$ whereas a $72.5 \%$ of increment for School B. Among the two schools, School B was discovered to have a higher percentage of increment, showing that the participants to have improve on their level of understanding towards the present continuous sentence construction. Based on the result, participant $\mathrm{G}$ was identified to have increase the most with an improvement of $80 \%$ from the Pre-Test to the Post Test. ** Why (justify it).The least differences in percentage between Pre-test and Post-Test was participant $C$ with an increment of $60 \%$. This showed that despite having the lowest percentage of improvement, participant $C$ still improved more than $50 \%$ showing that an improvement had happened after the implementation of the innovation. In line with the aim, the study showed that the Rainbow Tower had effect towards the teaching of Present Continuous Sentence.

To further support the claim on the effectiveness of the Rainbow Tower, the structured interview transcript affirmedthat with the aid of the innovation, the participants can construct sentences correctly or at least with minimal error. The interview also shown that the Rainbow Tower was towards the participants' liking, and that they were anticipated to use innovation alike to the Rainbow Tower. They approved the idea of using the Rainbow Tower again to learn to write sentences such as present tense and past tense sentences with one of the participants stating "Cikgu, boleh kita guna ini (Rainbow Tower) untuk belajar lagi?" ("Teacher, can we use this (Rainbow Tower) to learn more?"). These responses exhibited that the participants would not only increase the knowledge about present continuous sentence, but also motivated to learn using an interesting teaching aid. It helped to gain their attention towards learning and improved the learning environment for the students (Toikka, 2016) especially when learning a skill as complex as writing.

\section{Conclusion and Implications}

The major concern of this research was to explore the effectiveness of using fun learning strategy in teaching writing skills among rural primary pupils. Through this research, it was concluded that the 
Rainbow Tower had positive impact among the Year 4 pupils' ability in constructing present continuous sentences in the two schools in the interior of Sarawak. This was proven by the participants' accumulative scores and their responses from the interview. This research also showed that the tool teaching is fun and suitable for learning constructing sentence. It was displayed through their positive responses towards learning and their good scores in the writing test, indicating learning is retained (Dulay \& Burt 1977; Krashen 1982; Uzho \& Salame, 2016). Hence, The Rainbow Tower motivated the less proficiency and the low self-esteem pupils to participate in learning, helping the teacher to attract passive and slow learners. Significantly, this research has helped to broaden the horizon of researchers' knowledge and skills in teaching ESL in rural areas. This action research may also provide some ideas for English Language Teacher especially school in interior places without internet connection and limited facilities such as in Sarawak to be creative, resourceful and innovative to produce a conducive and fun learning environment.

\section{References}

Abdi, A. (2014). The Effect of Inquiry-based Learning Method on Students ' Academic Achievement in Science Course. Universal Journal of Educational Research, 2(1), 37-41. https://doi.org/10.13189/ujer.2014.020104

Bipinchandra, J. S. a/p, Shah, P. M., Puteh, S. N., Din, R., Rahamat, R., \& Aziz, J. A. (2014). User Needs Analysis in Learning Argumentative Writing via Mobile Platform. Procedia-Social and Behavioral Sciences, 118, 198-205. https://doi.org/10.1016/j.sbspro.2014.02.027

Graham, S., Gillespie, A., \& Mckeown, D. (2013). Writing : importance, development, and instruction. Springer Science+Business Media, (June 2012), 1-15.

https://doi.org/10.1007/s11145-012-9395-2

Huy, N. T. (2015). Problems affecting learning writing skill of grade 11 at Thong Linh High School. Asian Journal of Education Research, 3(2), 53-69.

Jha, S. K. (2014). Shall We Teach English as a Subject or as a Language ? Education Practice and Innovation, 1(1). https://doi.org/10.15764/EPI.2014.01004

Kurasaki, R., Bloor, K., Sy, M., \& Huguenin, C. (2017). Evidence-Based Assessment and Intervention for Problems with Writing in School Psychology Criteria for Written Expression. Springer International Publishing Switzerland 2017. https://doi.org/10.1007/978-3-319-45166-4

Lim, K. I., Yunus, M. M., \& Embi, M. A. (2017). Build Me Up : Overcoming Writing Problems Among Pupils In A Rural Primary School In Belaga, Sarawak, Malaysia. Jurnal Pendidikan Humaniora, 5(1), 1-7.

Madut, I. T., \& Yunus, M. (2016). Popsicle Simile : An Innovative Tool in Promoting Creative Writing among Rural Primary School ESL Learners. In Education in the 21th Century: Responding to Current Issues Popsicle (pp. 425-431).

Mokhtar, F. A. (1989). Rethinking Conventional Teaching In Language Learning And Proposing Edmodo As Intervention : A Qualitative Analysis. Malaysian Online Journal of Educational Technology, 4(2), 22-37.

Myhill, D., Jones, S., \& Wilson, A. (2016). Research Papers in Education Writing conversations : fostering metalinguistic discussion about writing. Research Papers in Education, 1522(March). https://doi.org/10.1080/02671522.2016.1106694 
Nunes, V. M. D. (2018). Learning to learn - using self-awareness of learning styles to promote language learning Inglês no $1^{\circ}$ Ciclo do Ensino Básico.

Suran, R. D. A., \& Yunus, M. M. (2016). A Survey on Students' Learning Styles and Strategies in a Rural Secondary School in Meradong District. In Education in the 21th Century: Responding to Current Issues.

Tan, C. (2017, March 25). Poor English skills a major complaint in every industry. The Star Online. Retrieved from https://www.thestar.com.my/news/nation/2017/03/25/poor-english-skills-amajor-complaint-in-every-industry/

Toikka, T. (2016). : A material package for introducing more kinaesthetic exercises into upper secondary school English classes.

Uzho, S. P. A., \& Salame, P. C. del R. M. (2016). USE OF BODILY-KINESTHETIC INTELLIGENCE THEORY TO IMPROVE THE CREATIVE LEARNING OF THE ENGLISH LANGUAGE IN STUDENTS OF 1ST EGB AT UNIDAD EDUCATIVA BILINGUE INSTITUTO PARTICULAR ABDÓN CALDERÓN.

Yap, W. L. (2016). Transforming Conventional Teaching Classroom to Learner-Centred Teaching Classroom Using Multimedia-Mediated Learning Module. International Journal of Information and Education Technology, 6(2), 105-112. https://doi.org/10.7763/IJIET.2016.V6.667

Yunus, M. M., \& Chan, H. C. (2016). The Use of Mind Mapping Strategy in Malaysian University English Test ( MUET ) Writing. Scientific Research Publishing, 7(April), 619-626.

Yunus, M. M., Salehi, H., Amin, M., Shojaee, M., \& Wang, Y. F. (2016). ACTIVITIES AND SUGGESTIONS FOR USING SOCIAL NETWORKING IN TEACHING ESL WRITING. Journal of Theoretical and Applied Information Technology, 84(2), 170-182. 